\title{
Revitalisasi Pengelolaan Bank Sampah Di Palabuhanratu
}

\author{
Budi Prasetyo Samadikun, Dwi Siwi Handayani, Muhamad Permana Laksana
}

\author{
Departemen Teknik Lingkungan, Fakultas Teknik, Universitas Diponegoro, Jl. Prof. Soedarto, \\ $\mathrm{SH}$, Kampus Undip Tembalang, Semarang, Indonesia 50275 \\ e-mail: budisamadikun@gmail.com
}

\begin{abstract}
Abstrak
Bank sampah di Kelurahan Palabuhanratu sudah berdiri sejak tahun 2010. Bank sampah ini adalah salah satu bank sampah diantara dua bank sampah lain, yang baru berdiri pada tahun 2016. Volume sampah pada tahun 2015 sebesar 134,89 $\mathrm{m}^{3}$ per hari, mencakup 89\% wilayah Kelurahan Palabuhanratu ternyata masih belum optimal dalam pengolahannya, karena sampah yang direduksi masih sekitar 5\% dari total timbulan sampah yang dikirim ke TPA Cimenteng yang berlokasi sekitar $70 \mathrm{~km}$ dari Kelurahan Palabuhanratu. Kinerja bank sampah eksisting masih kurang, karena satu bank sampah hanya mampu melayani satu RW dan belum dapat melayani satu kelurahan. Selain itu, pengolahan sampah organik untuk dijadikan kompos belum dilakukan secara serentak oleh seluruh masyarakat, karena pengetahuan masyarakat yang masih kurang. Tujuan penelitian adalah mengetahui kondisi eksisting pengelolaan sampah dan merumuskan upaya revitalisasi Bank Sampah eksisting sebagai pihak pendukung pengelolaan sampah di TPS Kelurahan Palabuhanratu. Metode penelitian menggunakan metode survei, dengan menggunakan kuesioner, wawancara mendalam, dan observasi. Teknik analisis menggunakan analisis kuantitatif dan analisis kualitatif. Hasil penelitian menunjukkan bahwa masyarakat yang melakukan pemilahan sampah dari sumber hanya penduduk RT 01 RW 33. Selain itu jumlah TPS di Kelurahan Palabuhanratu masih terbatas, sehingga membutuhkan tambahan 5 unit TPS yang terintegrasi dengan bank sampah di kelurahan ini.
\end{abstract}

Kata kunci: revitalisasi, bank sampah, Palabuhanratu

\begin{abstract}
The waste bank in Palabuhanratu Village has been established since 2010. This waste bank is one of the waste bank among two other waste banks, newly established in 2016. The volume of waste in 2015 is $134,89 \mathrm{~m}^{3}$ per day, covering $89 \%$ of Palabuhanratu Village area is still not optimal in its processing, because the reduced waste is still about $5 \%$ of the total waste generation delivered to the Cimenteng Final Diposal Site (FDS), which located about 70 $\mathrm{km}$ from Palabuhanratu Village. The existing waste bank's performance is still very poor, because one waste bank can only serve one RW and can not serve the entire village. In addition, the processing of organic waste to be compost has not been done simultaneously by the whole community, due to the lack of people's knowledge. The purpose of this research is to know the existing condition of waste management and to formulate the revitalization of existing waste bank. The research used survey research method by using questionaire, in depth interview, and observation. Analytical technique using quantitative and qualitative analysis. The findings shows that the residents of Palabuhanratu Village who often do waste sorting from the source only from the residents of RT $01 R W 33$. In addition, the number of existing temporary disposal site (TDS) in Palabuhanratu Village is still lacking, so it requires addition up to 5 units that integrated with waste bank in this village.
\end{abstract}

Keywords: revitalization; waste bank, Palabuhanratu

\section{PENDAHULUAN}

Kurang baiknya pengelolaan sampah di sebuah wilayah, akan menyebabkan pencemaran lingkungan di daerah tersebut. Kondisi ini akan berdampak pada kesehatan estetika, kerugian ekonomi, dan terganggunya ekosistem (Rahmadi, 2011). Dalam SNI 19-2454-2002 disebutkan bahwa sampah yang bersifat padat yang terdiri atas zat organik dan anorganik yang dianggap sudah tidak berguna lagi seharusnya dikelola agar tidak membahayakan lingkungan dan melindungi investasi pembangunan.

Beberapa kajian terhadap pengelolaan sampah sudah pernah dilakukan oleh peneliti terdahulu, diantaranya oleh Silalahi (2009) dan Naatonis (2010). Silalahi (2009) melakukan penelitiannya di pinggir Sungai Kapuas Kota Pontianak dengan metode 
kualitatif, salah satu tujuannya adalah untuk mengetahui pola pengelolaan sampah berbasis masyarakat di komunitas Kompleks Perumahan Dwi Ratna, dan menemukan bahwa pengelolaan sampah berbasis masyarakat yang diterapkan oleh komunitas ini dengan membuat pupuk kompos dilakukan secara individu dan membuat kerajinan tangan dilakukan dengan kelompok. Penelitian Naatonis (2010) dilakukan di Kampung Nelayan Oesapa Kupang dengan pendekatan kuantitatif-deskriptif untuk mengidentifikasi sistem pengelolaan sampah di Kampung Nelayan Oesapa Kupang. Hasil penelitian menunjukkan bahwa sistem pengelolaan sampah yang cocok adalah berbasis masyarakat dengan sebuah kerjasama dari masyarakat kampung nelayan, terutama dalam pelaksanaan kegiatan kebersihan lingkungan di lingkungan rumah tangga sendiri.

Salah satu solusi dalam pengelolaan sampah adalah dengan membuat bank sampah. Berdasarkan Peraturan Menteri Lingkungan Hidup No 13 Tahun 2012, Bank Sampah adalah tempat pemilahan dan pengumpulan sampah yang dapat didaur ulang dan/atau diguna ulang yang memiliki nilai ekonomi. Bank Sampah dapat berfungsi sebagai pelaksana reduce,reuse, dan recycle. Ruang lingkup Bank Sampah meliputi:

1. Persyaratan Bank Sampah, yaitu harus memiliki bangunan dan sistem manajemen.

2. Mekanisme Kerja Bank Sampah, meliputi pemilahan sampah, penyerahan sampah ke bank sampah, penimbangan sampah, pencatatan, hasil penjualan sampah yang diserahkan dimasukkan ke dalam buku tabungan, dan bagi hasil penjualan sampah antara penabung dan pelaksana.

3. Pelaksanaan Bank Sampah, meliputi penetapan jam kerja, penarikan buku tabungan, peminjaman uang, buku tabungan, jasa pemungutan sampah, jenis tabungan, jenis sampah, penetapan harga, kondisi sampah, berat minimum, dan wadah sampah.

4. Pelaksana Bank Sampah, memiliki peran sebagai fasilitator dalam pembangunan dan pelaksanaan bank sampah, menyediakan data "pengepul/pembeli sampah" bagi Bank
Sampah, menyediakan data "industri daur ulang", memberikan reward bagi Bank Sampah.

Damayanti dan Susilih (2014) telah melakukan sebuah penelitian yang membahas efektivitas pengelolaan sampah melalui bank sampah di Kecamatan Sukmajaya, Depok. Penelitian yang menggunakan pendekatan positivist dengan metode penelitian kualitatif, menghasilkan sebuah temuan bahwa pengelolaan sampah melalui bank sampah dengan studi bank sampah di Kecamatan Sukmajaya, Depok tidak efektif dilihat dari indikator kelembagaan, teknik operasional, pembiayaan, peraturan/ hukum, dan peran serta masyarakat.

Hasil wawancara penulis dengan Badan Lingkungan Hidup Kabupaten Sukabumi (2016) menyatakan bahwa terdapat tiga bank sampah yang ada di Kelurahan Palabuhanratu, satu bank sampah sudah berdiri sejak 2010 dan dua bank sampah lain mulai berdiri sejak awal tahun 2016. Volume sampah yang dihasilkan pada tahun 2015 sebesar 134,89 $\mathrm{m} 3 /$ hari yang mencakup $89 \%$ wilayah Kelurahan Palabuhanratu. Sampah yang dihasilkan tersebut berasal dari kegiatan rumah tangga, aktivitas di tempat pelelangan ikan, fasilitas umum, dengan kuantitas dan komposisi yang bervariasi. Namun pengolahan sampah dari sumber tersebut masih belum optimal karena sampah yang direduksi masih sekitar $5 \%$ dari total timbulan sampah yang dikirim ke TPA Cimenteng dengan lokasi berjarak 70 km dari Kelurahan Palabuhanratu.

Jarak tempuh yang jauh antara Kelurahan Palabuhanratu dengan TPA Cimenteng menyebabkan biaya operasional yang tinggi dan ritasi yang sedikit, sehingga pelayanan yang dilakukan oleh pemerintah Kabupaten Sukabumi belum berjalan optimal. Selain itu, masih minimnya kinerja bank sampah eksisting di Kelurahan Palabuhanratu yaitu satu bank sampah hanya mampu melayani satu RW. Jumlah tiga TPS eksisting ternyata tidak mampu melayani seluruh wilayah Kelurahan Palabuhanratu.

Tinjauan dari aspek kelembagaan, bank sampah eksisting di Kelurahan 
Palabuhanratu masih belum memiliki struktur yang jelas. Dalam operasional sehari-hari belum ada pihak yang bertanggung jawab atas keberlanjutannya. Selain itu, sampah organik yang diolah oleh sebagian masyarakat Kelurahan Palabuhanratu untuk dijadikan kompos belum dapat diterapkan oleh seluruh masyarakat, karena masih kurangnya pengetahuan masyarakat dalam mengolah sampah organik menjadi kompos.

Melihat fenomena yang terjadi di Kelurahan Palabuhanratu tersebut, perlu dilakukan upaya revitalisasi bank sampah agar bank sampah dapat berfungsi dengan lebih baik dalam pengelolaan sampah di Kelurahan Palabuhanratu. Perhatian dan kesadaran masyarakat menjadi faktor penting dalam mendukung keberhasilan pengelolaan sampah, sehingga tetap terjaga kualitas lingkungan di kelurahan ini.

Dalam penelitian Revitalisasi Bank Sampah di Palabuhanratu ini, hampir senada dengan Silalahi (2009) dan Naatonis (2010) yang mengidentifikasi pengelolaan sampah secara keseluruhan, maka penulis merumuskan dua tujuan utama, yaitu untuk mengetahui kondisi eksisting pengelolaan sampah di Kelurahan Palabuhanratu Kabupaten Sukabumi dan merumuskan upaya revitalisasi bank sampah eksisting sebagai sebagai pihak pendukung untuk pengelolaan sampah di TPS Kelurahan Palabuhanratu Kabupaten Sukabumi.

\section{METODOLOGI PENELITIAN}

Lokasi penelitian berada di Kelurahan Palabuhanratu Kecamatan Palabuhanratu Kabupaten Sukabumi. Letak TPS eksisting berada di tiga RW, yaitu RW 24, RW 30, RW 32 Kelurahan Palabuhanratu. Penelitian ini merupakan penelitian survei dengan menggunakan kuesioner, wawancara mendalam, dan observasi. Teknik analisis menggunakan analisis kuantitatif dan kualitatif. Jumlah responden sebanyak 100 orang yang tersebar di 35 RW, ditentukan dengan teknik purposive sampling. Kriteria responden adalah Kepala Keluarga (KK) yang tinggal di Kelurahan Palabuhanratu dengan kepadatan penduduk tertinggi dan ditemukan sampah tercecer di lingkungannya.

\section{HASIL DAN PEMBAHASAN}

\section{Kondisi Eksisting Pengelolaan Sampah di Kelurahan Palabuhanratu Kabupaten Sukabumi}

Berdasarkan hasil kuesioner, kondisi umum pengelolaan sampah Kelurahan Palabuhanratu adalah $42 \%$ baik dan $58 \%$ cukup. Persepsi masyarakat terhadap kondisi pengelolaan sampah berbeda-beda tergantung dari standar kebersihan dan kesadaran masyarakat dalam melakukan pengelolaan sampah, sebagaimana ditunjukkan pada gambar 1 .

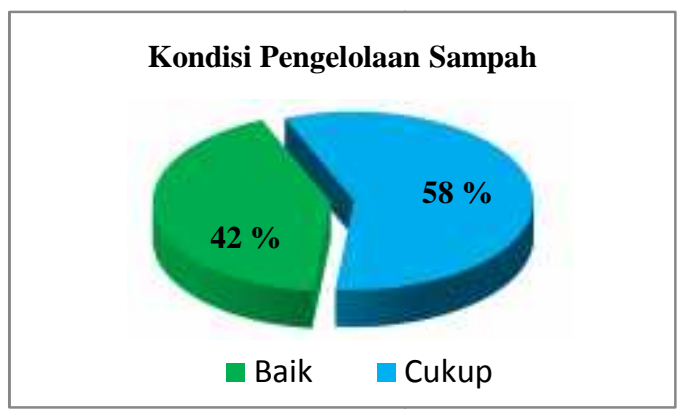

Gambar 1. Persentase Kondisi Pengelolaan Sampah

Pelaksanaan pengelolaan sampah dipengaruhi oleh beberapa faktor, salah satunya berasal dari aspek peran serta masyarakat yang dipengaruhi oleh pengetahuan masyarakat terhadap konsep 3R (Reduce, Reuse, and Recycle) serta kemauan dan kemampuan dalam pelaksanaan 3R tersebut. Pengalaman masyarakat dalam melakukan pemilahan sampah didapatkan persentase $20 \%$ responden selalu melakukan pemilahan sampah, $79 \%$ responden tidak melakukan pemilahan sampah dan $1 \%$ responden kadang-kadang melakukan pemilahan sampah, sebagaimana terlihat pada Gambar 2. Dari hasil tersebut dapat dinyatakan bahwa sebagian besar masyarakat masih kurang berpengalaman dalam melakukan pemilahan sampah. Satu hal yang sangat dibutuhkan dalam pengelolaan sampah adalah kesediaan/kemauan masyarakat untuk terjun langsung dalam melakukan pengelolaan sampah. Hal ini dapat dilakukan seperti membuang sampah pada tempatnya, melakukan pemilahan dari sumber, memanfaatkan sampah yang masih bisa dipakai ntuk mengurangi timbulan sampah, dan lain-lain, sebagaimana terlihat pada gambar 2 .

Sebagian besar warga Kelurahan Palabuhanratu sudah mengerti dalam tata cara melakukan pengomposan, yaitu sebanyak $69 \%$ responden. Terdapat $31 \%$ 
responden yang belum mengerti proses pengomposan didukung oleh temuan lapangan yaitu masih ditemukan warga masyarakat yang membuang sampah organik langsung ke tempat sampah, sebagaimana terlihat pada gambar 3 .

\section{Pemilahan Sampah}

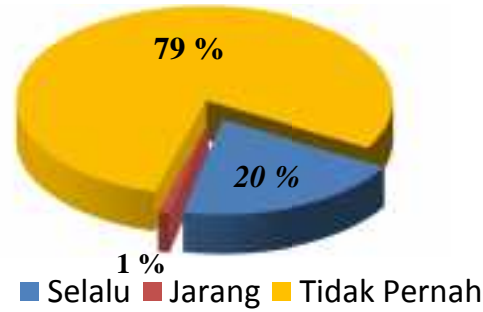

Gambar 2. Persentase Kondisi Pemilahan Sampah

\section{Pengetahuan Komposting}

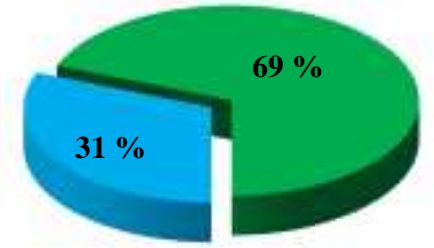

- Belum Paham $\quad$ Sudah Paham

Gambar 3. Persentase Pengetahuan Komposting Responden

Pengetahuan tentang Bank Sampah

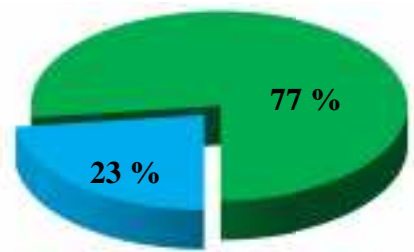

Belum Paham Sudah Paham

Gambar 4. Persentase Pengetahuan Responden tentang Bank Sampah

Warga Kelurahan Palabuhanratu memiliki pemahaman yang cukup baik terhadap bank sampah. Hal ini dibuktikan dari hasil kuesioner pada gambar 4, bahwa 77\% masyarakat Kelurahan Palabuhanratu mengetahui tentang bank sampah, dan hanya $23 \%$ responden tidak mengetahui. Berangkat dari kondisi ini, diharapkan di masa mendatang untuk sampah anorganik yang dijual ke bank sampah dapat dipisahkan dari sumbernya untuk mengurangi timbulan sampah.

\section{Bank Sampah Ratu Indah}

Jumlah bank sampah di Kelurahan Palabuhanratu ada 3 unit. Dua unit bank sampah sudah tidak beroperasi lagi karena kekurangan modal dan SDM, sedangkan yang beroperasi sampai sekarang adalah bank sampah Ratu Indah.

Bank sampah Ratu Indah terletak di RT 01 RW 33 yang berada di perumahan Bank Tabungan Negara (BTN) Pantai Ratu Indah. Pengelola bank sampah tersebut memiliki anggota sebanyak tiga orang dengan struktur anggota yaitu ketua, bendahara, dan sekretaris. Daerah pelayanan bank sampah Ratu Indah masih sebatas satu RT dengan tingkat pelayanan $67 \%$ yaitu 60 Kepala Keluarga dari total 90 Kepala Keluarga. Warga di perumahan BTN yang tidak menjadi nasabah bank sampah Ratu Indah adalah warga yang aktivitasnya sangat sibuk sehingga tidak sempat memilah sampah. Bank sampah Ratu Indah per bulannya dapat menghasilkan sampah sebanyak $200 \mathrm{Kg}$ yang terdiri dari besi, plastik, kardus, dan kaleng alumunium. Hasil dari pembelian sampah dari warga perumahan BTN dijadikan sebagai bahan baku untuk membuat kerajinan dan dijual ke pengepul. Keuntungan yang didapat per bulannya adalah 500 ribu.
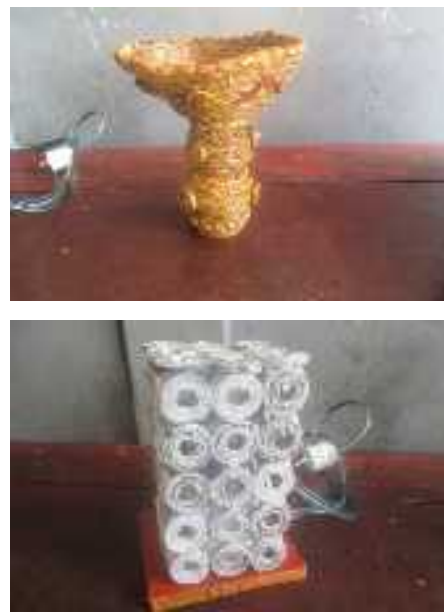

Gambar 5. Beberapa Produk Bank Sampah Ratu Indah

Berdasarkan wawancara dengan Ibu Maryatun sebagai Ketua Bank Sampah Ratu Indah menyatakan bahwa tujuan bank sampah dibentuk adalah untuk memperkenalkan arti sampah serta dampaknya kepada masyarakat dan juga 
untuk mensosialisasikan secara tidak langsung tentang pemilahan sampah. Sejak berdirinya bank sampah tersebut, sudah $60-70 \%$ masyarakat di sekitar bank sampah menjadi paham tentang fungsi dan manfaat dari bank sampah. Kendala yang dihadapi dalam mendirikan bank sampah tersebut adalah kurangnya sumber daya manusia untuk mengelola bank sampah sehingga pengelolaan belum dapat bekerja secara maksimal. Beberapa hasil karya Bank Sampah Ratu Indah tampak pada gambar 5.

\section{Pembentukan Kelompok Swadaya Masyarakat (KSM)}

Pengelolaan sampah di Kelurahan Palabuhanratu sebagian besar dilakukan oleh Dinas Tata Ruang, Pemukiman, dan Kebersihan Kabupaten Sukabumi didukung oleh RT/RW setempat, khususnya sistem pengumpulan dan pemindahan sampah dari rumah warga masyarakat menuju TPS. Sedangkan untuk sistem pengangkutan sampah dari TPS menuju TPA dikelola oleh Dinas Tata Ruang, Pemukiman, dan Kebersihan Kabupaten Sukabumi.

Dalam rangka mendukung pengelolaan sampah di Kelurahan Sukabumi, maka dibutuhkan sebuah struktur kelembagaan di tingkat kelurahan yang disusun oleh masyarakat melalui rapat warga dan terdiri dari berbagai komponen masyarakat, berbentuk Kelompok Swadaya Masyarakat (KSM). KSM ini yang nantinya melaksanakan dan mengawasi jalannya pengelolaan sampah dengan didampingi oleh instansi terkait. Struktur organisasi KSM di Kelurahan Palabuhanratu adalah sebagai berikut:

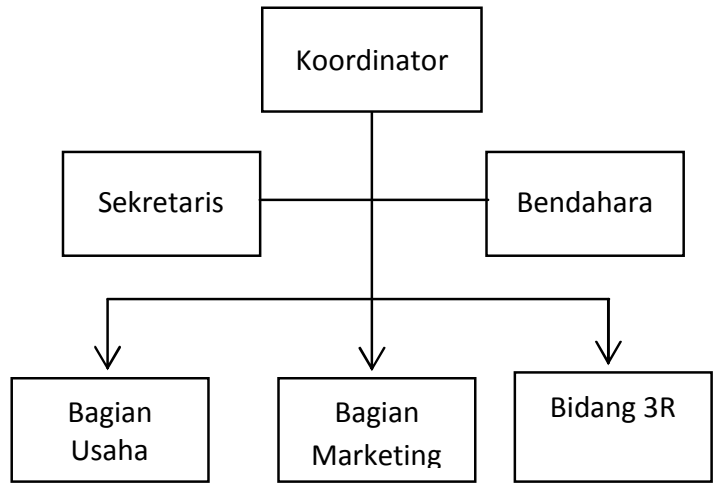

Gambar 6. Struktur KSM di Kelurahan Palabuhanratu

Struktur organisasi KSM yang akan terbentuk tersebut dalam pelaksanaannya mengacu pada hal-hal yang sudah diamanahkan dalam Peraturan Menteri Lingkungan Hidup No 13 Tahun 2012. Selain itu, sejalan dengan yang dinyatakan oleh Gouillart dan Elly (dalam Santoso, 2009) terkait dengan tiga pendekatan dalam revitalisasi organisasi, maka dalam struktur organisasi tersebut yang sangat berperan dalam pengembangan atau penggiatan Bank Sampah adalah Bagian Usaha, Bidang Marketing, dan Bidang $3 \mathrm{R}$ (Reduce, Recycle, Reuse). Bidang usaha bertanggung jawab mencari nasabah untuk bank sampah yang ada di TPS 3R dan juga bertanggung jawab dalam hal teknis pengumpulan. Bidang marketing melakukan koordinasi dengan pembeli sampah (industri, pengepul) untuk melakukan jual beli dan juga melakukan koordinasi dengan pemerintah daerah dan KSM lainnya. Koordinasi yang baik dan penuh sinergi antar berbagai pihak ini akan dapat mewujudkan keberlanjutan dan kelanggengan pengelolaan sampah di Kelurahan Palabuhanratu, sebagaimana yang telah terjadi di Kompleks Perumahan Dwi Ratna pinggir Sungai Kapuas Kota Pontianak (Silalahi, 2009) dan Kampung Nelayan Oesapa Kupang (Naatonis, 2010).

\section{Penambahan Jumlah Bank Sampah di TPS (Tempat Pembuangan Sampah Sementara)}

TPS eksisting di Kelurahan Palabuhanratu terdapat $3 \mathrm{RW}$, yaitu RW 24, RW 30, dan RW 32, yang kesemuanya belum berfungsi melakukan 3R (Reduce, Recycle, Reuse) dan memiliki lokasi yang kurang strategis untuk melayani pengangkutan sampah di Kelurahan Palabuhanratu.

Kondisi dan jumlah TPS eksisting yang kurang memadai tersebut harus ditambah secara jumlah dan fungsi, yaitu menjadi 5 TPS yang berfungsi melakukan 3R. Berdasarkan Gambar 7 dapat dilihat lokasi 5 TPS 3R yang diintegrasikan dengan Bank Sampah. Masing-masing TPS 3R tersebut memiliki wilayah pelayanannya masingmasing, TPS 3R I melayani RW 20, RW 21, dan RW 33, karena lokasi RW tersebut sangat berjauhan dengan RW yang lain sehingga pengelolaan sampahnya dibuat secara terpisah. Sedangkan untuk TPS 3R II-V melayani lebih dari $3 \mathrm{RW}$ karena letak RW-nya yang berdekatan.Wilayah pelayanan masing-masing bank sampah dapat dilihat pada tabel 1. 
Tabel 1. Daerah Pelayanan TPS 3R

\begin{tabular}{cccc}
$\begin{array}{c}\text { TPS } \\
\text { 3R }\end{array}$ & $\begin{array}{c}\text { Total Wilayah Pelayanan } \\
(\mathrm{RW})\end{array}$ & Wilayah Pelayanan (RW) & $\begin{array}{c}\text { Volume Timbulan } \\
\text { Sampah }\left(\mathrm{m}^{3} / \text { hari) }\right.\end{array}$ \\
\hline I & 3 & $20,21,33$ & 11,116 \\
II & 9 & $6,7,8,9,10,11,12,13,16$ & 21,364 \\
III & 9 & $23,24,25,26$, & 24,390 \\
IV & 7 & $27,28,29,30,34$ & 22,366 \\
V & 7 & $1,2,3,4,5,31,35$ & 20,34 \\
& 35 & $14,15,17,18,19,22,32$ & 99,576 \\
\hline
\end{tabular}

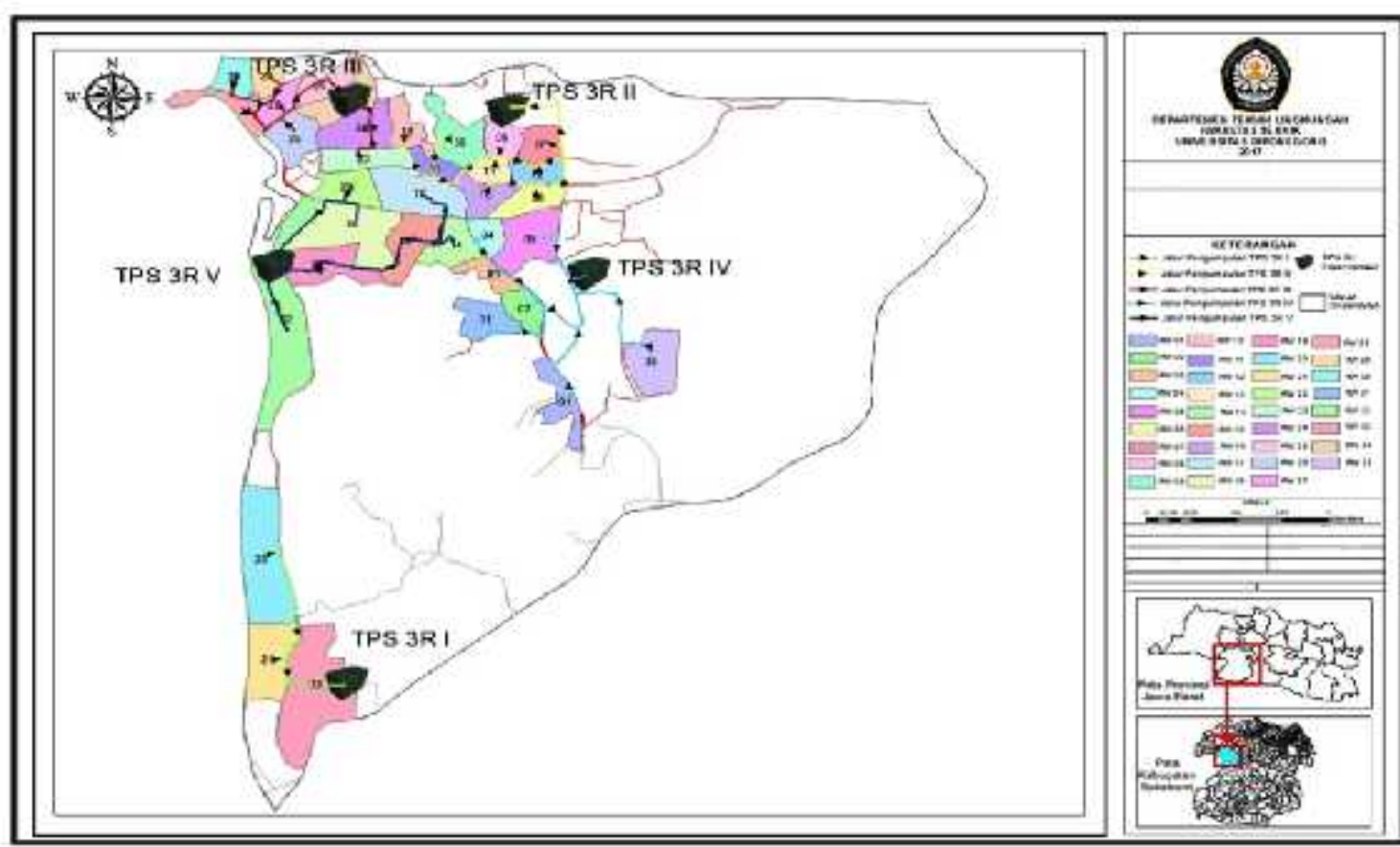

Gambar 7. Daerah Pelayanan TPS 3R (Bank Sampah)

\section{KESIMPULAN}

Penimbunan sampah di TPS maupun TPA bukan merupakan sebuah penyelesaian yang bijaksana karena setiap hari volume sampah dapat dipastikan selalu bertambah. Lahan penampungan semakin berkurang dan dampak buruk di sekitar lokasi penampungan kian hari semakin bertambah. Bank Sampah merupakan salah satu upaya konkret untuk meminimalisir banyaknya sampah di masyarakat yang beum terkelola dengan baik. Penelitian ini merupakan contoh nyata penerapan bank sampah yang belum optimal di Kelurahan Palabuhanratu. Ada dua hal yang dapat dilakukan dalam merevitalisasi sebuah bank sampah, diantaranya:
1. Membuat sebuah struktur pengelolaan sampah di kelurahan yang dikoordinatori oleh Kelompok Swadaya Masyarakat. KSM inilah yang nantinya berfungsi sebagai penggerak dan penggiat bank sampah di Kelurahan Palabuhanratu

2. Penambahan jumlah TPS dan memfungsikannya sebagai TPS $3 R$ yang didalamnya terintegrasi dengan bank sampah

Kesuksesan berjalannya revitalisasi bank sampah membutuhkan dukungan pemerintah untuk membuat regulasi khusus terkait bank sampah, sehingga pengelola maupun pelanggan bank sampah tersebut lebih memiliki kepastian dan juga semangat untuk terus berperan aktif di ranah ini. 


\section{DAFTAR PUSTAKA}

Badan Lingkungan Hidup Kabupaten Sukabumi interview. 2016. Pengelolaan Bank Sampah di Palabuhanratu. Citepus, Pelabuhan Ratu, Sukabumi, West Java

Badan Standar Nasional. 2002. SK SNI 19-2454-2002 Tentang Tata Cara Teknik Operasional Pengolahan Sampah Perkotaan. Jakarta : Balitbang DPU

Rahmadi, Takdir 2011. Hukum Lingkungan di Indonesia Sebuah Pengantar. Jakarta: Sinar Grafika

Damayanti, R. dan Susilih, S. 2014. Efektivitas Pengelolaan Sampah melalui Bank Sampah. Studi tentang Bank Sampah di Kecamatan Sukmajaya, Depok. Skripsi. Program Studi Ilmu Administrasi Negara Universitas Indonesia.

Naatonis, R.M. 2010. Sistem Pengelolaan Sampah Berbasis Masyarakat di Kampung Nelayan Oesapa Kupang. Tesis. Magister Teknik Pembangunan Wilayah dan Kota Universitas Diponegoro.

Santoso, W. 2009. Revitalisasi Dewan Pendidikan Dalam Peningkatan Mutu Pendidikan di DKI Jakarta. Tesis. Program Pascasarjana IImu Administrasi FISIP Universitas Indonesia.

Silalahi, Mery. 2009. Pengelolaan Sampah Berbasis Masyarakat Studi Kasus RT 02 RW 07 Kelurahan Benua Melayu Laut, Kecamatan Pontianak Selatan Kota Pontianak, Provinsi Kalimantan Barat. Tesis. Sekolah Pasca Sarjana Institut Pertanian Bogor. 